\title{
MICROECONOMICS OF ARCHITECTURE: BETWEEN MARKET AND PUBLIC
}

\author{
Valentinas Navickas, Tomas Skripkiūnas \\ Kaunas University of Technology
}

\begin{abstract}
The position of architecture between market goods and public goods is addressed in this study. A transition of architectural objects of built environment from market goods towards public or nonmarket goods is presented in literature review. The real estate market value is highly influenced by concepts of externalities and public goods, therefore being highly spatially dependent and making the process of the real estate valuation more complex. The internalization of these externalities and public goods is impossible because of the nature of public space in the city. The concept of value and different types of value, like exchange, use, image, social, environmental, cultural value, are also presented in literature review. These different types of value are transferred to value in exchange when estimating market value. The aim of research is to calculate the amount of the real estate market value that is influenced by externalities, public or nonmarket goods. The process of value transfers between market and public is also discussed in this study. In the research part prices of similar apartments in cities of Kaunas, Vilnius and Klaipeda (Lithuania) are compared to measure the coefficient of variance. Newly constructed apartment buildings with partial finishing interior within city boundaries are selected expecting their price to vary only because of different amount of externalities and public goods available inside district/region of selected building or provided by the actual building itself. The results show that up to $29 \%$ of the real estate market value is influenced by public or nonmarket goods. Implications of further research suggest controlling for market segmentation and architectural quality variables.

KEY WORDS: microeconomics of architecture; architecture; real estate; market value; public goods; externalities.
\end{abstract}

\section{Introduction}

Impact of architectural quality on real estate market value is discussed in this study. The aim of this research is to establish a methodological background for understating the position of architecture between public goods and market goods.

Architecture is defined and perceived as the art and science of designing space in this study. The focus is on space rather than objects, either between buildings or inside them. Furthermore, a broader definition of architecture is used which includes the design of the total built environment from the macro level of town planning, urban design and landscape architecture to the micro level of construction details and, sometimes, furniture.

Architectural quality can have various methods how it can be measured. However, this is not discussed in this study. It is presumed that bigger investment in architecture means better quality of architectural surroundings overall (this might not be the case in some situations but is the desired outcome). However, the allocation of initial endowment between public goods and market goods is assessed in the research and discussion part of this study.

The evaluation of architectural surroundings is based on the idea of Pareto efficiency involving all players that have interrelationships with architecture under consideration, including producers and consumers of it (consumers of architecture as public good and market good). Real estate market value is reflected by its price, although there are nonmarket aspects of real estate value.

Architecture and built environment have different meanings in this study: built environment refers to physical objects of architecture (not only buildings but streets, bridges, sidewalks, landscape structures, as well as small scale architecture et cetera) while architecture is used to express the design of those objects.

\section{Literature review}

Market goods. Here we look at buildings as singular objects. There are lots of hedonic price models of real estate where buildings are market goods. In those models, determinants of real estate market price are various attributes of buildings that have influence on price.

If we look at built environment as a market good, we see it as a product with its price. Regarding the looks, various studies show that architectural quality has impact on selling and rent prices. It was showed that in downtown Chicago new commercial buildings that won architectural awards had higher rent levels (Hough \& Kratz, 1983). Commercial buildings that were rated highly by architects in Boston and Cambridge also had higher rent levels (Vandell \& Lane, 1989). A price premium for certain architectural styles was found in Newburyport, Massachusetts (Asabere et al., 1989) or Netherlands. Also, the market value of the real estate is driven by expectations and desires, therefore design trends and irrational behaviour over time become apparent (Navickas \& Skripkiūnas). Although looks, whether inside or outside, are important, nothing that is not exclusively dedicated to its owner utility directly adds up to its price. There is where architecture as an externality emerges.

Externalities. Here we look at buildings as singular objects related to other singular objects. "We say that an economic situation involves a consumption externality if one consumer cares directly about another agent's production or consumption" (Varian, 2006). Therefore, a 
consumption externality in real estate is very common as we perceive buildings in their architectural surroundings. "Similarly, a production externality arises when the production possibilities of one firm are influenced by the choices of another firm or consumer" (Varian, 2006). Therefore, also, architects are highly influenced by site restrictions when designing a building.

There is no market for better architectural surroundings, but we are highly influenced by them. Market value becomes dependent on externalities (production and consumption of neighbouring architectural objects). "However, there are other social institutions such as the legal system, or government intervention that can "mimic" the market mechanism to some degree and thereby achieve Pareto efficiency" (Varian, 2006). Regulations and municipality administration can take this part.

With a conviction that real estate market value is highly spatially dependent, location variables are becoming ubiquitous in hedonic price models. These may include methods to capture distance to city focal points, spillovers of value of other buildings or objects. We can find a lot of research focussing on identifying house price determinants related to their location and surroundings. It is confirmed that real estate data is highly spatially dependent (Wilhelmsson, 2002). Spatial modelling was used to incorporate spillovers of house prices into the traditional hedonic model for decades (Can, 1990; Anselin, 1988) (LeSage \& Pace, 2009), there is research done how to better incorporate those spatial econometric models in recent studies in Athens (Stamou et al., 2017). Spatially weighted regression or spatial econometrics are being widely used.

It is demonstrated that there are spillovers of quality design. Buildings care a lot about the looks of built environment that surrounds them. This hypothesis can be tested "by looking at the price impact of attractive neighbouring buildings" (Glaeser et al., 2018) or distance to urban focal points, and their influence on rent prices (Gat, 1998). It was shown that houses designed by Frank Lloyd Wright has a positive effect on prices of houses nearby (Ahlfeldt \& Mastro, 2012). It is difficult to measure quality of the surroundings, however various attempts are being pursued.

Furthermore, abandoned or poorly maintained buildings are negative externalities. Similar to various examples of pollution, owners of such properties should face social cost of their actions. The concept of network externalities and two-sided markets is important in city planning. Schools, day care centres, kindergartens, shops, restaurants and other social infrastructure are undersupplied in new housing areas, because their market decisions may not meet the needs of residents.

There would definitely be incentives to internalize such externalities acquiring public values of quality surroundings. "If the actions of one affect the other, then they can make higher profits together by coordinating their behaviour than by each going alone" (Varian, 2006). However, the separation of public and private space in the city is so deeply embedded in our consciousness and subconscious that main structure of city space cannot be internalized (there are other reasons for this, but this is not in the scope of this study). There is where architecture as a public good emerges.

Public goods. Here we look at buildings as complexes and structures. Not all externalities can be internalized in the district or city. "As soon as there are more than two economic agents involved things become much more difficult" (Varian, 2006). Although different locations can have different levels of architectural quality which might result in local externalities, quality of architectural surroundings is such a widely available externality that everyone in the city must consume the same amount of it, therefore becoming public good.

Many public goods are provided by the government. Public space in cities like streets, squares, parks, sidewalks are all the same for everyone to use. Local municipalities are supposed to cover the need for architectural elements that serve the need for public goods. As municipalities are not able to fully satisfy the need for quality architectural surroundings, this should be accompanied by building owners. However, tragedy of the commons or free riding is becoming more apparent. Players in real estate market are neglecting the need for social infrastructure and quality public spaces, therefore resulting in lower overall value of their developments (as the demand for such developments is related to nonmarket or public goods in that area).

Architectural design as public good or widely available externality has impact on many economic activities: it is a huge externality for real estate market, it is a tool for attracting consumers and producers to the city, advertising quality of life. There are studies that link tourism sector with architectural surroundings "that enhances the special local characteristics of place through unique design qualities that tourists are attracted to consume" (Scerri et al., 2019) resulting in consumption of space and economic activity in particular areas of the city (Aranburu et al., 2016). The quality of built environment cuts deeply into our mental maps of cities.

Value. A problem of different meaning of the concept of value is important here. Value is usually interpreted as a monetary amount for exchange between a willing buyer and seller in an open market. Furthermore, two different types of value can be defined:

- Value in exchange is the quantity of other commodities (normally cash) a commodity can be swapped for (Carmona et al., 2001). This type of value is often called market value or price.

- Value in use is often associated with the concept of worth or the pleasure a commodity generates for its user. It is important to say that worth is not the same as price as there are various irrational variables in the real estate market. Also, the valuation of real estate differs widely between individuals, different locations and in time (Nase et al., 2015).

International Valuation Standards Council (IVSC) and Royal Institution of Chartered Surveyors (RICS) defines market value as:

- Market Value is the estimated amount for which an asset or liability should exchange on the valuation date between a willing buyer and a willing seller in an arm's length transaction, after proper marketing and where the parties had each 
acted knowledgeably, prudently and without compulsion (RICS, 2017).

This definition, being too money-centred, lacks the broader consideration of other economic and social dimensions (Nase et al., 2015). According to Macmillan (2006) Built environment can be associated with a range of different types of value that may alter the overall valuation process:

- Exchange value. Built environment has influence on what people are willing to pay for any objects of built environment when traded.

- Use value. Built environment has influence on organizational outcomes such as productivity, profitability, competitiveness, effectiveness.

- Image value. Built environment has influence on corporate identity, prestige, vision, reputation, and organizational values. It can contribute to design excellence, innovation and brand image.

- Social value. Built environment has influence on social interaction, social identity, safety and security. It can encourage positive change or prevent vandalism and crime.

- Environmental value. Built environment has influence on sustainability by using principles of adaptability and flexibility, robustness, low maintenance and whole-life cost approach.

- Cultural value. Built environment has influence on intangible phenomenon like context, sense of place, symbolism, inspiration, aesthetics.

It is interesting that value is transferred from all types described above to the first value in exchange. "This translation process is based on interdependent economic factors that create value, namely utility, scarcity, desire and effective purchasing power" (AI, 1996). "Utility is the ability of a good to satisfy needs. Scarcity is the supply of an item relative to the demand for it. If demand is constant the scarcity of a commodity makes it more valuable. In the case here, reduced quantities of a quality (urban design) product due to initial investment costs reflect its price in the market. Because it is inefficiently priced, urban design (as a public good product) is undersupplied by property development and house building industry. Desire is a purchaser's wish for a commodity to satisfy needs beyond the essential required to support life. This is considered in direct relation to quality as the willingness to pay a higher price for higher utility. Finally, effective purchasing power is the ability of purchasers to participate in the market" (Nase et al., 2015) (Webster, 2007, 2010). We can say that exchange value sums up all types of value.

Value transfers resulting in the market value which reflects the whole set of values confirm the definition by Royal Institution of Chartered Surveyors, saying that market considers all types of value when defining it as an exchange value. According to utility theory, user utility is maximized as all types of value are added (Nase et al., 2015). However, it is difficult to say whether the whole set of values is reflected in the real estate market value.

Nonmarket goods. Similar to value in exchange and value in use, the word value can also be used in two different ways:
- Which is desirable or worthy of esteem for its own sake; thing or quality having intrinsic worth (ecologists' point of view) (Neufeldt, 1997).

- A fair or proper equivalent in money, commodities, etc (economists' point of view) (Neufeldt, 1997).

This corresponds to a distinction made by philosophers between intrinsic value and instrumental value. "If it is valuable in and for itself - if its value is not derived from its utility, but is independent of any use or function it may have in relation to something or someone else $[\ldots]$ an intrinsically valuable entity is said to be an 'end-in-itself', not just a 'means' to another's ends" (Callicott, 1989) . In contrast, something has instrumental value if it is valued as a means to some other end or purpose. In this view, the value of something lies in its contribution to some other goal (Costanza \& Folke, 1997; Champ et al., 2003). Having intrinsic values, architecture is partly nonmarket good. This can be evaluated but not to be traded in the market.

We do not explicitly purchase nonmarket goods. However, we do purchase other goods which demands are linked with nonmarket goods (Champ et al., 2003). Architecture cannot be separated from the built environment and nature that it is embedded in, hence real estate value is linked to its surroundings, the environment and resources.

Welfare. Finally. There may be many Pareto efficient allocations between market and public, however distribution of welfare across people is an important goal, because architectural surroundings are one of very basic needs of people. This enhances the importance of value distribution between market goods and public goods. Built environment bears the task to support people with environment for every use and creativity, therefore cost of achieving this contributes to achieving welfare across districts, cities or even countries. This goal can only be achieved collectively.

\section{Research and discussion}

Understanding types of value built environment can generate, we can draw a conclusion that some types of architectural quality are market goods while others are public or nonmarket goods (Fig. 1). At the same time, talking about individual objects of architecture, they are externalities to other objects. Network externalities may be detected too. Internalization of architectural externalities is limited due to the nature of city public space. Therefore, architecture as a public good is a significant factor of economic activity in the city as can be shown with examples of tourism sector.

Calculating the impact of public goods on the real estate market value would be tough initially, therefore, this study is trying to measure the variance in market value because of externalities and public goods. Items of similar properties were selected for this task:

- Function - housing, type - apartments;

- Construction year - between 2018 and 2020;

- Partial finishing;

- Location - inside city territory.

We are looking at price per square metre to adjust for apartment size. It is assumed that volatility of the price is 
because of the public/nonmarket goods available in the district/region of the selected buildings or public/nonmarket goods provided by the selected buildings themselves. However, there are some limitations to this research. Construction cost, land availability and price are not evaluated in this research. It is presumed in this study that quality of the actual housing units varies equally across selected items.
Dataset from Lithuanian real estate advert website "Aruodas.lt" (https://www.aruodas.lt) is used for this research. Although about $10 \%$ discount should be taken off asking prices on the website to reflect the actual market values, this has no influence on the scope of this study because prices are compared to each other so the overall price level is not significant.

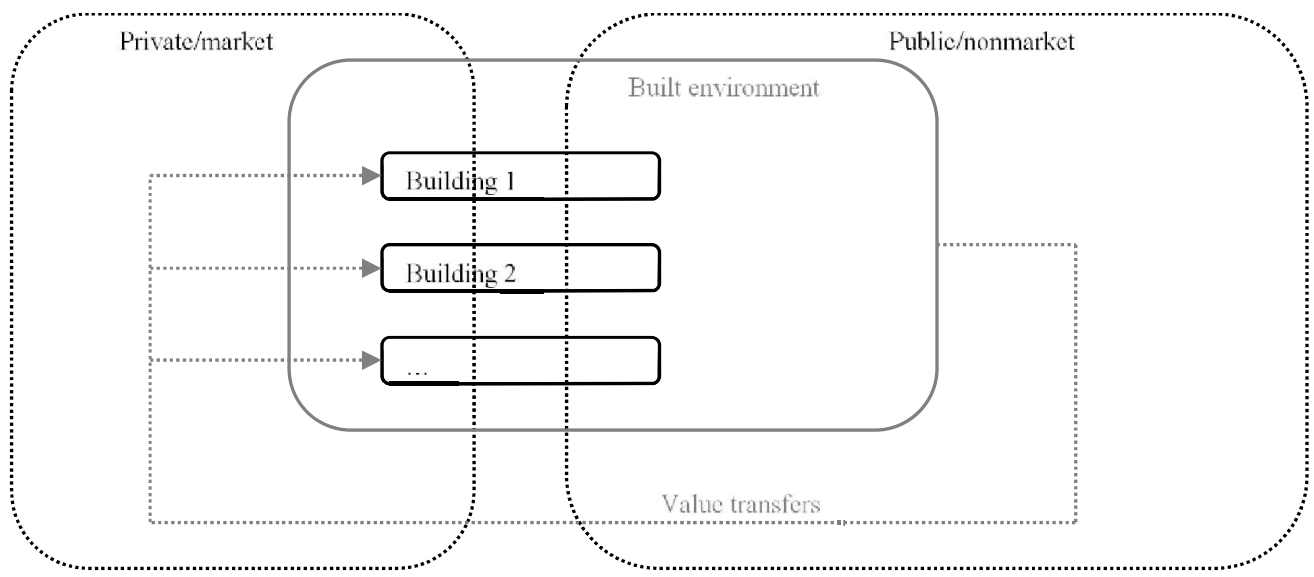

Fig. 1. Framework for positioning buildings between market and public

The span of available prices of apartments in cities of Kaunas, Vilnius and Klaipeda (Lithuania) are presented (Fig. 2-5). Apartments are listed in price ascending order on horizontal axis in graphs. Price per square meter is on vertical axis. Standard deviation and coefficient of variance are calculated as a measure for public goods related variance in market value:

- Kaunas. 264 observations. Average price - 1391 $€ / \mathrm{m}^{2}$. Standard deviation $-351 €$. Coefficient of variance $-25 \%$.

- Vilnius. 727 observations. Average price -2170 $€ / \mathrm{m}^{2}$. Standard deviation $-821 €$. Coefficient of variance $-38 \%$.

- $\quad$ Klaipeda. 78 observations. Average price -1532 $€ / \mathrm{m}^{2}$. Standard deviation $-281 €$. Coefficient of variance $-18 \%$.
We are looking for consistency as well as differences between cities although number of observations differ. We can see that Vilnius has market segment of higher prices $(>150000 €)$ where significantly higher prices per square meter are observed. Further research is needed to understand what drives the real estate market value higher. Therefore, those results were excluded and dataset of apartments with asking price up to $150000 €$ was used (Fig. 4):

- Vilnius $(\leq 150000 €) .533$ observations. Average price $-1844 € / \mathrm{m} 2$. Standard deviation - $540 €$. Coefficient of variance $-29 \%$.

The results suggest $18-29 \%$ variation of newly constructed apartments with partial finishing interior within city boundaries if it would be the same size.

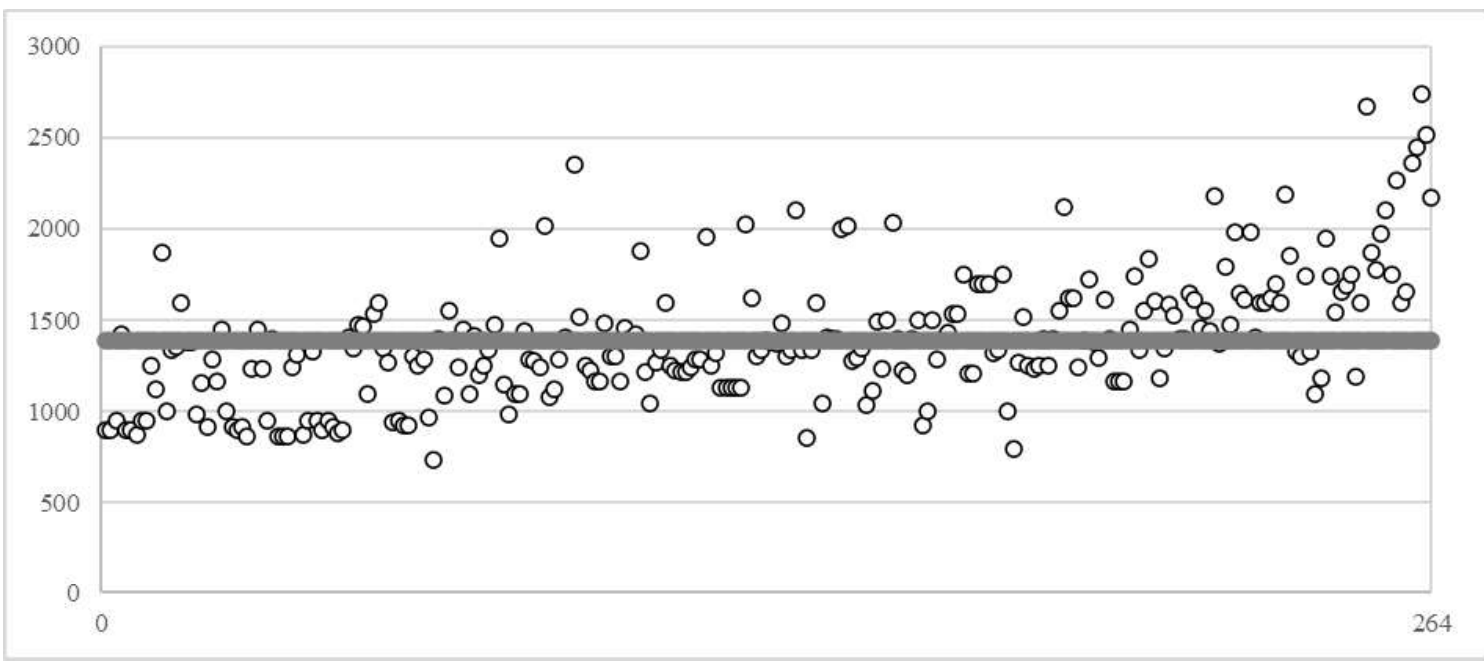

Fig. 2. Market value of apartments in Kaunas, $€ / \mathrm{m}^{2}$ 


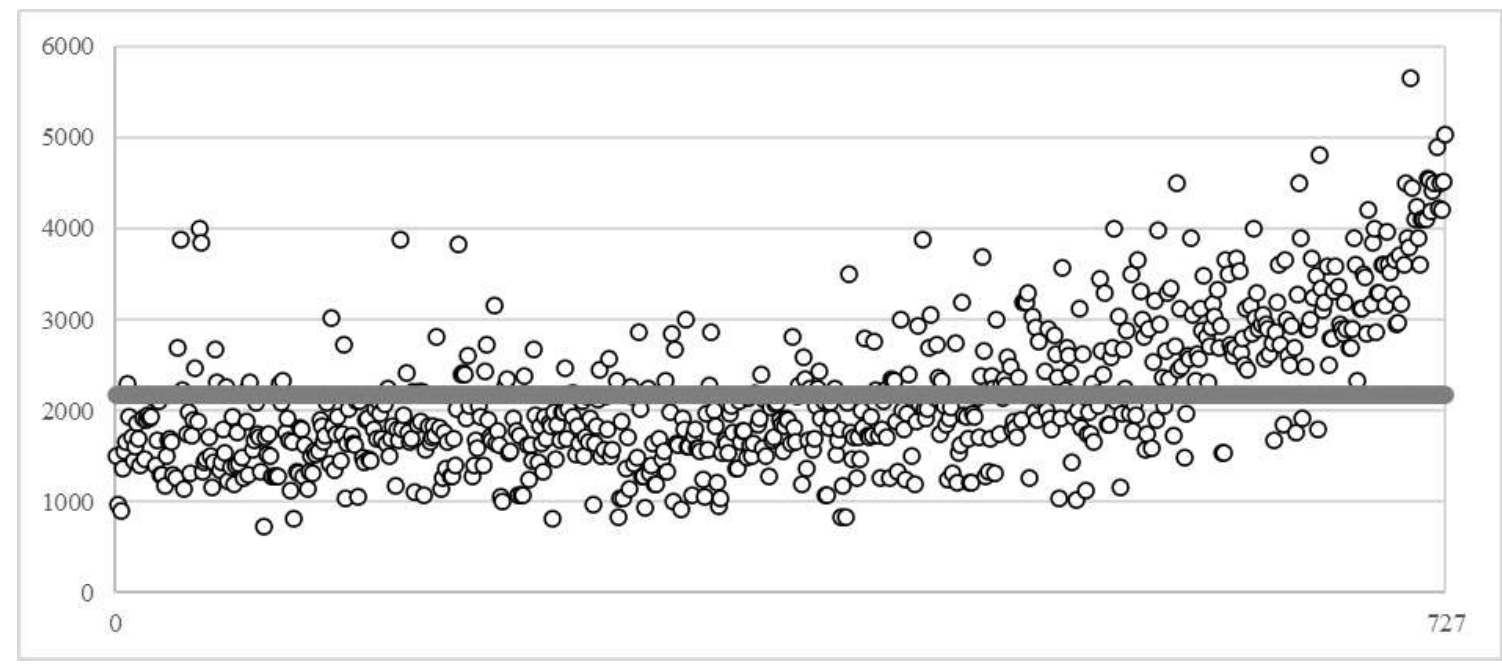

Fig. 3. Market value of apartments in Vilnius, $€ / \mathrm{m}^{2}$

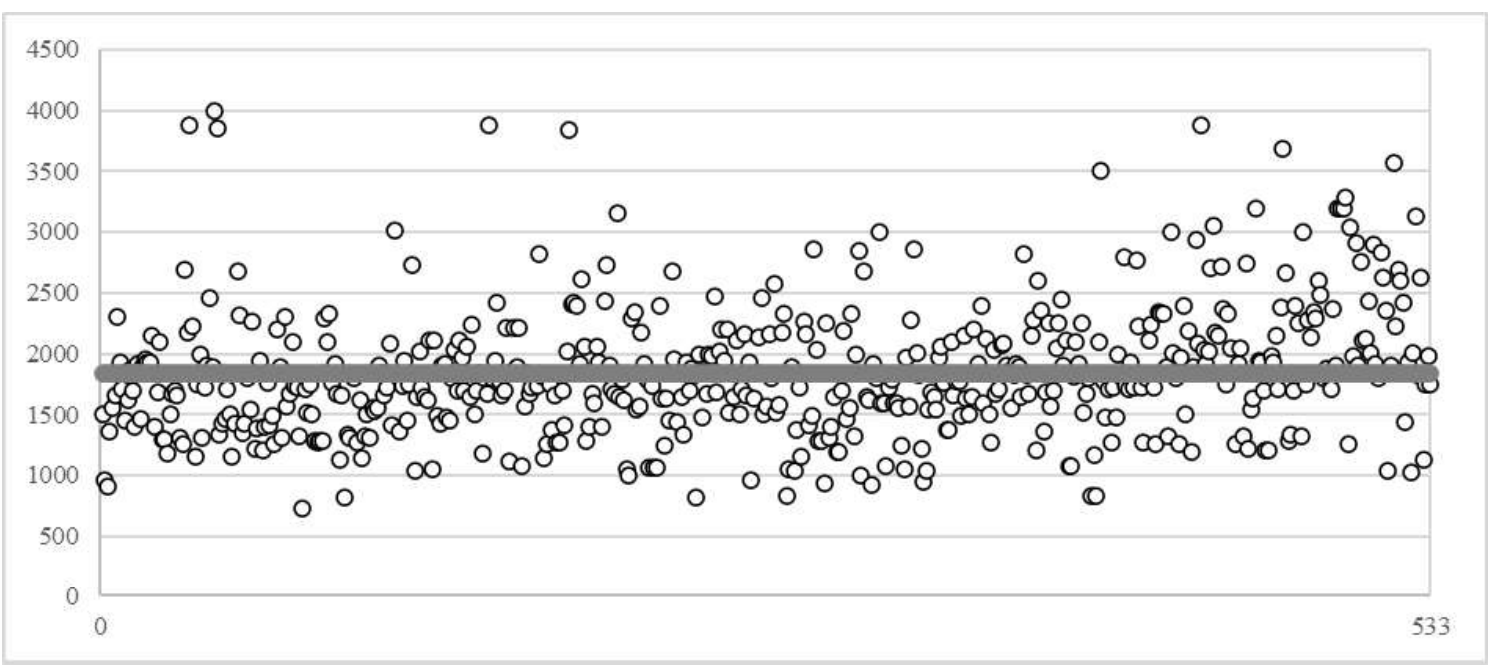

Fig. 4. Market value of apartments in Vilnius $(\leq 150000 €), € / \mathrm{m}^{2}$

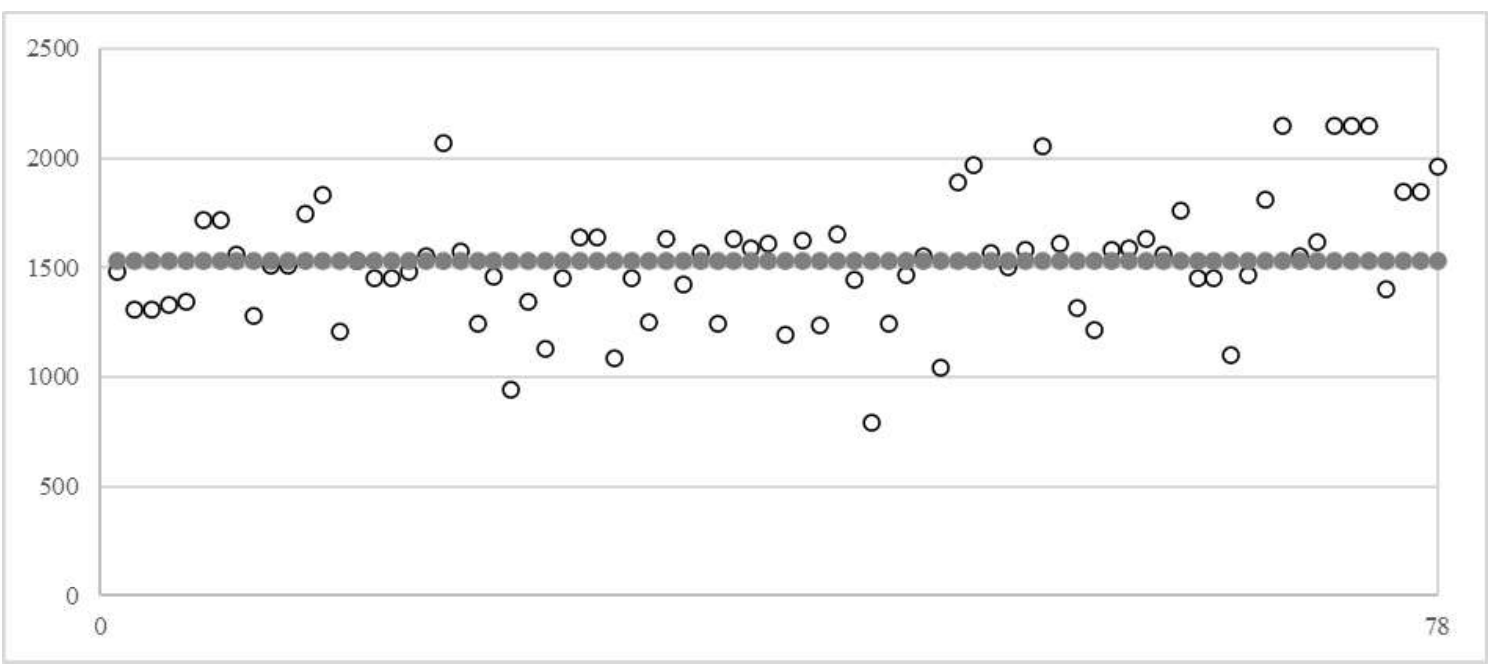

Fig. 5. Market value of apartments in Klaipeda, $€ / \mathrm{m}^{2}$ 


\section{Conclusions}

Value of built environment is split between market goods and public goods. There are a lot of hedonic price models of the real estate that carefully estimates price determinants, also adding location variables or even architectural quality variables. However existing research is fragmented and lacks comprehensive analysis about balance between market and public goods in the field of built environment. According to literature review, the important part is a translation of values that contribute to public or nonmarket goods, to value in exchange that reflects the market value or price.

According to the study of Lithuanian housing market we can observe up to $29 \%$ variation in apartment market value because of factors that relate to externalities and public or nonmarket goods. There are differences between cities resulting in higher variation of apartment market value in bigger cities with more housing projects available. The results suggest that there is a significant portion of market value created by the quality of our surroundings.

Limitations and future research suggestions include more architectural quality variables to be added to this study. An unobserved heterogeneity between apartments and their attributes could be examined in more detail. Market segmentation could be important factor while selecting data for further research.

\section{References}

Ahlfeldt, G., \& Mastro, A. (2012). Valuing Iconic Design: Frank Lloyd Wright Architecture in Oak Park, Illinois. Housing Studies, 27(8), 1079-1099. https://doi.org/10.1080/02673037.2012.728575

AI. (1996). The appraisal of real estate. Appraisal Institute.

Anselin, L. (1988). Spatial econometrics: methods and models. Kluwer Academic Publishers.

Aranburu, I., Plaza, B., \& Esteban, M. (2016). Sustainable Cultural Tourism in Urban Destinations: Does Space Matter? Sustainability, 8(8), Article 699. https://doi.org/10.3390/su8080699

Asabere, P., Hachey, G., \& Grubaugh, S. (1989). Architecture, historic zoning, and the value of homes. J Real Estate Finan Econ, 2(3), 181-195. https://doi.org/10.1007/BF00152347

Callicott, J. B., \& Shaner, D. E. (1989). In Defense of the Land Ethic: Essays in Environmental Philosophy. State University of New York Press.

Can, A. (1990). The Measurement of Neighborhood Dynamics in Urban House Prices. Economic Geography, 66(3), 254272. https://doi.org/10.2307/143400

Carmona, M., De Magalhaes, C., Edwards, M., Awuor, B., \& Aminossehe, S. (2001). The Value of Urban Design. Thomas Telford
Champ, P. A., Boyle, K., \& Brown, T. C. (2017). A Primer on Nonmarket Valuation. Dordrecht: Springer.

Costanza, R., \& Folke, C. (1997). Valuing ecosystem services with efficiency, fairness and sustainability as goals. In G. Daily (Ed.), Nature's Services: Societal Dependence on Natural Ecosystems (pp. 49-70). Island Press.

Gat, D. (1998). Urban Focal Points and Design Quality Influence Rents: The Case of the Tel Aviv Office Market. The Journal of Real Estate Research, 16(2), 229-247.

Glaeser, E. L., Kincaid, M. S., \& Naik, N. (2018). Computer Vision and Real Estate: Do Looks Matter and Do Incentives Determine Looks. National Bureau of Economic Research Working Paper Series, No. 25174. https://doi.org/10.3386/w25174

Hough, D. E., \& Kratz, C. G. (1983). Can "good" architecture meet the market test? Journal of Urban Economics, 14(1), 40-54. https://doi.org/10.1016/0094-1190(83)90028-1

Le Sage, J. P., \& Pace, R. K. (2009). Introduction to Spatial Econometrics. CRC Press.

Macmillan, S. (2006). Added value of good design. Building Research \& Information, 34(3), 257-271. https://doi.org/10.1080/09613210600590074

Nase, I., Berry, J., \& Adair, A. (2015). Urban design quality and real estate value: in search of a methodological framework. Journal of Urban Design, 20(5), 563-581. https://doi.org/10.1080/13574809.2015.1071657

Navickas, V., \& Skripkiūnas, T. (2020). Macro dynamics of the real estate market value: temporal effects. Torun International Studies, $\quad 1, \quad 119$. https://doi.org/10.12775/TIS.2020.009

Neufeldt, V., \& Guralnik, D. B. (1997). Webster's New World college dictionary. Macmillan.

RICS. (2017). RICS Valuation - Global Standards. Royal Institution of Chartered Surveyors.

Scerri, M., Edwards, D., \& Foley, C. (2019). Design, architecture and the value to tourism. Tourism Economics, 25(5), 695-710. https://doi.org/10.1177/1354816618802107

Stamou, M., Mimis, A., \& Rovolis, A. (2017). House price determinants in Athens: a spatial econometric approach. Journal of Property Research, 34(4), 269-284. https://doi.org/10.1080/09599916.2017.1400575

Vandell, K. D., \& Lane, J. S. (1989). The Economics of Architecture and Urban Design: Some Preliminary Findings. Real Estate Economics, 17(2), 235-260. https://doi.org/10.1111/1540-6229.00489

Varian, H. R. (2006). Intermediate microeconomics: a modern approach (7th ed. ed.). Norton.

Webster, C. (2007). Property Rights, Public Space and Urban Design, Urban Planning. Town Planning Review, 78, 81101. https://doi.org/10.3828/tpr.78.1.6

Webster, C. (2010). Pricing accessibility: Urban morphology, design and missing markets. Progress in Planning - PROG PLANN, 73, 77-111. https://doi.org/10.1016/j.progress.2010.01.001

Wilhelmsson, M. (2002). Spatial Models in Real Estate Economics. Housing, Theory and Society, 19(2), 92-101. https://doi.org/10.1080/140360902760385646

\section{RECEIVED: 1 October 2020}

\section{ACCEPTED: 1 December 2020}

Valentinas Navickas. Doctor of social sciences (economics), professor at Kaunas University of Technology (Lithuania), School of Economics and Business. E-mail: valna@ktu.lt. Author of more than 350 scientific publications (including monographies published in Czech Republic in 2013 and Slovak Republic in 2016, 2018) and scientific articles, published in Lithuania and abroad. Prepared 7 doctors of social (economics) science; now he is research adviser of 3 persons maintaining a doctor's thesis of social (economics) science. Fields of scientific interest: logistics, clusterization, competitiveness, economic growth.

Tomas Skripkiūnas. PhD student at Kaunas University of Technology (Lithuania), School of Economics and Business. E-mail: tomas.skripkiunas@ktu.edu. Fields of scientific interest: architecture, real estate, sustainability. 